\section{Urban governance and the systems approaches to health-environment co-benefits in cities}

\author{
Governança urbana e a abordagem por sistemas \\ para co-benefícios saúde-ambiente em cidades
}

\author{
Governanza urbana y el enfoque sistémico- \\ analítico para co-beneficios salud-ambiente \\ en ciudades
}

\author{
${ }^{1}$ Institute for the Advanced \\ Study of Sustainability, \\ United Nations University, \\ Tokyo, Japan. \\ 2 Escola Brasileira de \\ Administração Pública e de \\ Empresas, Fundação Getulio \\ Vargas, Rio de Janeiro, Brasil. \\ 3 International Institute \\ for Global Health, United \\ Nations University, Kuala \\ Lumpur, Malaysia. \\ 4 Instituto COPPEAD de \\ Administração, Universidade \\ Federal do Rio de Janeiro, Rio \\ de Janeiro, Brasil. \\ 5 French National Center \\ for Scientific Research, Lille, \\ France. \\ ${ }^{6}$ National Institute for \\ Environmental Studies, \\ Tsukuba, Japan. \\ Correspondence \\ J. A. P. Oliveira \\ Institute for the Advanced \\ Study of Sustainability, \\ United Nations University. \\ 5-53-70 Jingumae, \\ Shibuya-ku, Tokyo/Tokyo - \\ 150-8925, Japan. \\ japo3@yahoo.com
}

\begin{abstract}
The term "co-benefits" refers to positive outcomes accruing from a policy beyond the intended outcome, often or usually in other sectors. In the urban context, policies implemented in particular sectors (such as transport, energy or waste) often generate multiple co-benefits in other areas. Such benefits may be related to the reduction of local or global environmental impacts and also extend into the area of public health. A key to identifying and realising co-benefits is the adoption of systems approaches to understand intersectoral linkages and, in particular, the translation of this understanding to improved sectorspecific and city governance. This paper reviews a range of policies which can yield health and climate co-benefits across different urban sectors and illustrates, through a series of cases, how taking a systems approach can lead to innovations in urban governance which aid the development of healthy and sustainable cities.
\end{abstract}

Public Policies; Health Impact Assessment; Urban Health
Jose A. Puppim de Oliveira 1,2,3,4

Christopher N. H. Doll 1,3

José Siri 3

Magali Dreyfus 5

Hooman Farzaneh 1,6

Anthony Capon ${ }^{3}$

\section{Resumo}

“Co-benefícios” é um termo que se refere aos impactos positivos de uma política além do que se era esperado inicialmente. No contexto urbano, políticas executadas em um setor específico (como transporte, energia ou resíduos) frequentemente podem gerar múltiplos co-benefícios em outras áreas, como redução dos impactos ambientais globais e locais, e se extendendo à saúde pública. Um ponto chave para se poder identificar e gerar co-benefícios é adotar a abordagem por sistemas para entender as ligações inter-setoriais. Esta abordagem também pode ajudar no entendimento de como podemos melhorar um setor específico e a governança urbana em geral. Assim, este artigo faz uma revisão da literatura de várias políticas que geram co-benefícios climáticos e de saúde em diversos setores e ilustra através de uma série de casos como a abordagem por sistemas pode levar a inovações em governança urbana que levem ao desenvolvimento de cidades mais sustentaveis e saudáveis.

Políticas Públicas; Avaliação do Impacto na Saúde; Saúde Urbana 


\section{Introduction}

The collective pressure of human activities is affecting planetary systems 1,2 , in large part through the transition of human populations to urban lifestyles 3 . This transition forms the backdrop for a range of imminent concerns relating to urban health and wellbeing and global environmental change. Some challenges, like climate change, obesity, and global biodiversity loss, are unprecedented in history and seem to increase inexorably, intractable to policy efforts at even the highest levels. Others, like urban air pollution, infectious disease outbreaks, or casualties from extreme events, involve phenomena for which the necessary tools for measurement, prediction and policy action have long existed, as evidenced by their effective control over long periods, yet which evade preventive efforts in the modern urban context, particularly in the developing world. Policy resistance in such situations often reflects the lack of a systemic approach to the interconnected determinants of urban health, which in turn, is intrinsically linked to deficits in governance.

Systems problems arise, in this setting, out of synergies between decision-making and the driving forces of modernization in complex urban environments. Such problems are best addressed through systems approaches designed to characterize and manage complexity while accounting for differing viewpoints and incentives among varied stakeholders, and acknowledging the distributed nature of knowledge and expertise. In particular, effective governance to improve health and wellbeing in cities requires an accurate and accessible evidence base and inclusive decision-making processes that are both streamlined and implementable across a range of urban contexts.

Although such problems are found in many domains, the focus here is on the interactions between climate change, urban health and wellbeing, and urban planning. This paper examines the key role played by improved urban governance in facilitating the application of systems approaches to urban health. In particular, we argue that better recognition of the climate co-benefits in health (i.e. "win-win" situations in which action to mitigate climate change also leads to improved health) would lead to an improvement in urban governance and allow for a more effective approach to health in cities. This is a particularly relevant context in which to apply systems approaches, since innovative solutions can be identified and implemented locally. This is critically important at the city scale 4 , where decisions at higher levels can lag or are absent altogether.
In order to examine systems approaches to health/environment co-benefits in cities, this paper provides a systematic discussion of the linkages between climate change, health and wellbeing, and governance in the urban context, collecting and summarizing relevant literature in these areas. However, owing to the combined breadth of these topics, the authors acknowledge that this is neither a comprehensive literature review nor a meta-analysis with specific search criteria and keywords commonly found in the public health literature. The topics under consideration are very broad and may be discussed in publications that do not necessarily feature the relevant keywords (for example, many discussions on urban energy are in publications analyzing energy generation more generally). Indeed, such a review would be prohibitively long for this publication. We therefore suggest this paper be taken as a conceptual analysis rather than a systematic review.

We initially summarize the health impacts of climate change in cities and the general foundations of systems approaches. We then typify health/climate co-benefits in different urban sectors, consider the characteristics of systems thinking in the specific context of improvements in urban governance, and illustrate these concepts via a set of case examples.

\section{The impacts of climate change on health in cities}

\section{Patterns of climate change}

The anticipated effects of climate change are wide-ranging, but their extent and geographic distribution depends on collective decisions made over the next few decades to curb greenhouse gas (GHG) emissions, limit biodiversity loss and moderate consumption. Even if mean global temperature rise is limited to $2^{\circ} \mathrm{C}$, which for many now seems unlikely, certain effects such as sea-level rise have become unavoidable. Other patterns can be forecasted with some degree of confidence. For example, it is likely that storm systems will become larger and stronger, and that droughts and heatwaves will intensify 5,6,7. Climate change-induced food and water security are also major concerns in some geographic zones (e.g., as a result of accelerated desertification in Sahelian Africa) ${ }^{8}$, as is consequent population movement on mass scales ${ }^{9}$. 


\section{Climate impacts on health in cities}

In general, climate effects on health can be categorized as primary - encompassing direct climatic environmental exposures; secondary - involving disruptions to ecosystems; or tertiary - involving social and economic disruptions driven by climate change 10,11,12 (Table 1 ).

At all scales, cities are at particular risk for adverse health outcomes from climate change 13 . For one, cities concentrate people and infrastructure, leaving them more vulnerable to focal extreme climate events (e.g., hurricanes, droughts) - such events can impact cities directly or indirectly, through food supply chains, regional economic impacts and other pathways. Given the necessity of water for human life and livelihoods, urban settlements are often coastal, and therefore often at high risk from sea-level rise or hydrological or geological events 14 . Indeed, there is concern that sea-level rise will displace significant populations in the coming century 15 , many of which will migrate to cities unprepared to absorb these new residents.

Moreover, because cities are where most people now live, they bear increased vulnerability in situations of local resource scarcity, such as droughts and famines, which impact their catchment areas. Issues of scarcity are to some extent offset by the greater connectivity urban areas enjoy compared to remote rural zones, but even well-connected cities can be overwhelmed by severe shortages, particularly in the developing world, where economic resources are insufficient to offset shortfalls. As with sea-level rise, scarcity-inducing events can also spur increases in migration 16.
Attributes of the built environment in cities generate micro-environmental conditions that can generate unique risks in conjunction with climate change - for example, urban heat islands act synergistically with more frequent and intense heat waves to enhance health risks from thermal stress 17 , and urban agriculture or green space can generate risk for vector-borne diseases $18,19,20$, which may themselves undergo geographic expansion with a warming climate 21 . In a similar vein, the byproducts of urban activity (e.g., air pollution) can act in synergy with climatic factors to enhance health risks (e.g., allergic respiratory ailments) 22,23.

The relationship between urbanization, urban metabolism and climate change is, moreover, bidirectional - i.e., cities also affect climate, given that they are the origin of most resource demand and the location of most consumption. Cities may account for over $80 \%$ of global GHG emissions ${ }^{3}$. The impact of cities on climate change is one link in a reinforcing feedback chain that ultimately has major consequences for human health and wellbeing 24 .

\section{Unequal impacts}

Inequity in impacts and resilience is a critical dimension of urban vulnerability to climate change. On a micro scale, slums and informal settlements, generally occupied by the poor, face disproportionately greater risks related to climate change 25 and health 26 . They are often unplanned, lacking both the infrastructure and service base of wealthier neighborhoods. They are more frequently populated by recent migrants than are other areas, and may thus lack networks for social support. Moreover, they are often sited

Table 1

Climatic effects on health.

\begin{tabular}{|c|c|c|c|}
\hline & Climatic effects & Examples of health effects & Time scale \\
\hline Primary & $\begin{array}{l}\text { Direct effects from, e.g., temperature change, } \\
\text { altered precipitation patterns, or sea level rise }\end{array}$ & $\begin{array}{l}\text { Acute exposure to heat or cold; chronic stress from } \\
\text { heat or cold; trauma from flooding, fires or storms; } \\
\text { acute population displacement or water deficits }\end{array}$ & Usually immediate \\
\hline Secondary & $\begin{array}{l}\text { Indirect effects from, e.g., altered distributions } \\
\text { of vectors, intermediate hosts \& pathogens, or } \\
\text { interactions between climatic change \& other }\end{array}$ & $\begin{array}{l}\text { Changed epidemiology of infectious diseases; } \\
\text { synergistic non-linear health effects arising from } \\
\text { interacting phenomena (e.g., allergies in the }\end{array}$ & Medium-term \\
\hline & phenomena like air pollution & presence of extreme heat events \& air pollution) 22 & \\
\hline Tertiary & $\begin{array}{l}\text { Effects arising from interactions between climate, } \\
\text { politics \& ecology }\end{array}$ & Famine; war; population displacement & Long-term \\
\hline
\end{tabular}

Note: adapted from Butler \& Harley 10 
in areas that may, a priori, carry higher environmental risks (e.g. on floodplains or steep slopes).

More broadly, it is likely that impacts from climate change will most strongly affect developing-world regions - a particularly egregious asymmetry, given the vast imbalance in per capita emissions between high- and low-income countries and communities 5 .

\section{Systems approaches}

It is increasingly recognized that complex problems of urban management and development require approaches that go beyond traditional norms in scientific inquiry and policy-making $4,24,27,28$. This is particularly evident with respect to assuring urban health and wellbeing in the context of climate change. Conventional approaches often fail to achieve long-term objectives because they (a) focus on limited, siloed or less-relevant aspects of the problem; (b) lack an effective interface between those responsible for constructing the evidence base and those that make decisions; (c) fail to account for adverse incentives on the part of either scientists or decision-makers in urban planning and management; or (d) fail to integrate insights and knowledge from these various domains 29. Systems approaches are designed to effectively address these concerns. We distinguish four main elements of such approaches, relating to analytic method, interdisciplinarity, transdisciplinarity, and scaling/bounding.

\section{Analytic method}

Traditional methods in epidemiology and other public health sciences tend to be reductive: that is, they focus on identifying the independent effects of individual variables. While there is no denying the historical value such work has brought to the study of health, or indeed its present utility in situations where causality is straightforward, reductive methods tend to fail in the face of complexity, such as seen in urban systems - for example, where feedback structures, dynamic decision-making processes or threshold effects produce non-linear relationships.

Ever-more-intricate empirical statistical analyses of association have made substantial inroads in identifying complex causal relationships - e.g., through the use of latent variable approaches, multilevel and structural equation modeling. Yet such relationships are often best identified through dynamical systems modeling approaches, broadly defined (Hovmand 30 explores the circumstances under which the two techniques can represent non-linear and feedback relationships). Such approaches explicitly incorporate feedback structures, threshold effects and other nonlinearities, allowing for simulation, scenario testing, the identification of systemic leverage points, and optimization. They may also include individual-based or aggregate models, structured spatially or along network frameworks at multiple scales.

\section{Interdisciplinarity}

Beyond systems-based analytic methods, a key element of systems approaches is scientific and/ or professional interdisciplinarity. A defining characteristic of urban systems is complexity, and the more complex the system, the less likely that any one practitioner - or set of researchers from a single disciplinary field - can accurately define the scope of the problem or the system in question. Interdisciplinarity involves integrating the disciplinary knowledge (i.e., concepts, methods and principles) of practitioners from different fields to develop a shared more complete understanding of a problem 31 .

Systems approaches thus necessarily involve not only teams of scientists from substantially different disciplinary backgrounds, but also urban design professionals - as well as methods for blending knowledge, identifying key commonalities and differences in understanding, harmonizing data design and collection, and recognizing valid systemic relationships 32 . In this regard, cognitive science can and should play a significant role, however a substantial shift in attitudes on the part of scientists, planners and ancillary communities (including funding agencies) is also needed.

\section{Transdisciplinarity}

Understanding how to resolve real-world problems goes well beyond identifying causes and effects in vitro or in silico. In particular, it requires understanding how incentive structures and the variable behavior of different stakeholders affect the feasibility of policy actions, and how dynamic changes in the system in response to policy can lead to new incentives for decision and policymakers and the general population - and, no less, for the scientific community. Moreover, it involves translating new understandings of system behavior into actionable recommendations.

Tackling such questions involves transdisciplinarity - the incorporation of stakeholders beyond traditional science (or urban engineering and design, in this context) in defining systems, setting goals, and generally participating in the 
co-production of knowledge. This is necessary to provide an accurate understanding of feasibility and incentives, to sensitize scientists and urban planners to the political and policy context - and conversely, decision-makers to the evidence base - and to generate the will for sustained collective action. Effective transdisciplinary approaches also incorporate communities and citizens, and hence increase accountability among decisionmaking entities.

\section{Scaling/bounding}

One persistent issue with systems problems is the likelihood that both causes and effects will cross institutional, physical or geographic decision-making boundaries. Such transboundary problems complicate effective short- and longterm control efforts in that decision-making entities often lack control of the causes of problems within their jurisdictions. Conversely, many of the consequences of their decisions may be felt outside their ambit. This is particularly true for cities, which drive environmental impacts over a much broader footprint than the urbanized zone and which are vulnerable to health consequences from processes occurring far beyond their borders.

Systems approaches address the multi-scale nature of systems problems by incorporating stakeholders from multiple geographic, disciplinary and decision-making domains and by explicitly modeling multi-scale effects.

\section{Co-benefits in cities: linking climate change and urban health across multiple sectors}

The reduction of carbon emissions lies at the heart of current efforts to combat climate change, yet it also has consequences for urban health. Actions under this strategy broadly fall into two logical categories, namely shifting from carbon-intensive fuels to cleaner forms of energy and increasing energy efficiency. While such efforts find their broadest expression in nationallevel energy policy, the complexity of the systems that give rise to carbon emissions leads to a diversity of implementations in different sectors and across different levels of governance.

Thus, in the transport sector, reduction of carbon emissions is often characterized by an improvement in vehicle efficiency and shift from private vehicles to public transit options. Yet because carbon reductions have as much to do with extent of travel as they do with mode of travel, solutions supersede technical considerations to encompass those social and economic dimensions of urban lifestyles which generate the need to take trips 33 . The way cities are laid out and the relative locations of goods and services are also clearly relevant to travel and emissions. Land use affects the amount of green space in a city, which in turn can alter urban heat island effects and consequently energy demands from buildings - also affected by building design and the efficiency of home appliances. A range of climate mitigation benefits can also be obtained from the waste sector in terms of how waste is sorted and processed 34 . It becomes clear that a range of interlinked planning and regulatory actions, when tackled simultaneously, can give rise to significant reductions in climate-altering pollutants 35 .

Each of the structural factors and policy options described in the preceding paragraph also has local consequences for health. These overlapping effects allow for the identification of co-benefits between actions designed to reduce carbon emissions and consequent health outcomes. "Co-benefits" is a term increasingly widely used in discussions on climate change policy - it essentially refers to the planned ancillary benefits of any given policy 36 . In reality, most policies imply a range of outcomes (intended and unintended; positive and negative); therefore, understanding the effects of policies in sectors beyond their original scope is critical. Emerging research is now explicitly focusing on the kinds of co-benefits that can accrue from well-planned interventions in different urban sectors 35 . Climate co-benefits in health encompass win-win opportunities for simultaneously tackling climate change and improving health. Ideally, systems approaches can help identify synergies and trade-offs across sectors, yet the potential opportunities and benefits of applying such approaches in health promotion remain relatively undeveloped in practice ${ }^{37}$. This section briefly outlines potential sectors where co-benefits for health are anticipated.

\section{Transport}

Urban transport affects health in various interconnected domains: respiratory and other ailments resulting from air pollution produced in the combustion of fuels; physical injury which may result from high speeds or traffic volumes or design characteristics of the built environment; stress and other factors affecting mental health that arise from features of transport or mobility, such as time spent commuting; and cardiovascular and other health risks arising from the increasingly sedentary nature of modern life - in part the result of planning decisions about 
transport which lead to a lack of physical activity. There is a growing body of evidence regarding the deleterious health effects arising from these various sources. Of these, physical inactivity, which has soared over the last few decades, appears to pose the greatest health risks, as it has a direct relation with obesity, diabetes and cardiovascular disease. In a study comparing London and Delhi, "active transport" (walking and cycling) offered the greatest health benefits in terms of disability adjusted life years (DALYs), by an order of 5-10 over switching to cleaner fuels alone, whilst a combination of both strategies was found to be even more beneficial 38 .

Concern initially manifested over the relationship between urban transport and health in areas where widespread car use first proliferated 39 . Pendola \& Gen 40 reported a relationship between urban density and car use and between critically increased body-mass index (BMI) values for users who reported high levels of car use. Although the US has some of the highest obesity rates in the world, Day et al. ${ }^{41}$ also reported rapidly increasing levels of obesity linked to increased car use and low-density residential living in China. The complex of characteristics of modern urban organization which provide the conditions for physical inactivity in a population have been labelled the "obesogenic urban form" 42,43 .

Despite advances in vehicle technology, many cities in the world still experience unacceptable levels of air pollution. For example, Doll 44 estimated that over three-quarters of a billion people are exposed to $\mathrm{PM}_{10}$ levels exceeding even the least-stringent World Health Organization (WHO) pollution control guidelines in urban areas. Exposure to air pollution increases morbidity and mortality from respiratory illnesses and cardiovascular disease; in 2012, there were 3.7 million premature deaths related to outdoor air pollution 45 . Many of these could be prevented by reducing dependence on private motor cars and shifting to clean public transport as well as active transport. Whilst necessary, such a shift is not sufficient and the integration of sustainable transport planning into the built environment is crucial. For example, the provision of walkable and cyclable areas is essential to ensure that gains from active transport are not offset by increased risk of collision with motorized vehicles.

\section{Land use}

The health benefits of sensibly planned urban areas, and particularly so-called "green infrastructure" 46, are manifold. Green areas cool cities, countering the urban heat island effect, and filter the air of pollutants; they also act as loca- tions where residents can exercise and engage in other outdoor activities. When sited as communal parks, village greens and town squares, they can also foster a sense of community, social cohesion and even build an appreciation of nature and environmental responsibility. Other types of green infrastructure such as wetlands or urban forests may also provide environmental co-benefits such as water filtration and storm water regulation 46 .

Tzoulas et al. 47 cite a range of experimental and epidemiological studies and surveys which indicate benefits from green spaces, related to the innate need of humans for contact with nature for psychological well-being; among these are increased longevity, better self-reported health outcomes, greater relaxation levels, quicker recovery from stressful situations, and lessened aggression as a result of reduced fatigue. Bowler et al. 48 systematically reviewed evidence of benefits from exposure to natural environments, finding overall improved levels of energy and decreased negative emotions such as anxiety, anger, fatigue and sadness.

However, the positive benefits of green spaces cannot be generalized 47 ; ecological changes in urban and peri-urban areas can, for example, affect the range of vector-borne diseases like Lyme disease and West Nile Virus. Planning in itself does not guarantee positive health outcomes. In Putrajaya, a planned city and the administrative capital of Malaysia, the desire to create an "intelligent garden city" with green areas and water features combined with other aspects of urban governance resulted in some of the highest levels of dengue fever in Malaysia 49. For greatest effect, planning must be embedded in a systems approach which accounts for systemic change and unintended consequences.

\section{Urban energy}

The chief health impact of the urban fuel cycle derives from incomplete combustion when fuel carbon is converted to health-damaging pollutants. About half of the world's households (mainly rural) use solid fuels (biomass and coal) for cooking and heating in simple devices that produce large amounts of air pollution 50 . Although the use of biomass is lower in cities, poor populations in cities still use a range of fuels which cause adverse health effects.

In developing countries, significant health co-benefits can be achieved by replacing existing inefficient indoor and outdoor cooking systems with increased-efficiency, low-emission stoves and also by improving the energy efficiency of appliances in buildings, which would result in 
substantial health benefits through the reduction of respiratory infection and adult heart and lung disease. Using such methodologies, a case study in Delhi showed that a five year program to introduce low-emission cooking and high-efficiency ventilation systems could prevent around 1 million premature deaths, particularly from cardiovascular mortality and chronic obstructive pulmonary disease (estimate by authors).

Impacts can also be made on the demand side of the energy equation. Improving ventilation performance in an attempt to reduce energy demand not only reduces air-flow from outdoor air pollution but also reduces fossil fuel consumption in power plants, which has an indirect effect on health protection in cities. Distributed power generation through multiple micro generation facilities is expected to play an increasingly important role in cities, and such new modes, in tandem with energy generation from renewable resources, are seen as critical for meeting GHG reduction targets - although this is not only an urban issue. Changing methods of electricity generation to reduce GHG emissions, particularly by reducing the use of coal, would reduce particulate air pollution $\left(\mathrm{PM}_{10}\right.$ and $\left.\mathrm{PM}_{2.5}\right)$ that can harm health. Mitigating climate change via intervention in the urban energy system thus presents excellent opportunities for improving public health through reductions in acute respiratory infections, tuberculosis, chronic bronchitis and lung cancer 51 .

Poorly constructed and maintained houses are more likely to be inhabited by people with low incomes and this too has an indirect effect on health 52. Developing methods for retrofitting low-income apartments and single-room occupancies that achieve energy savings and simultaneous indoor air quality improvements can make residents more resilient to increasing energy prices and improve their health. Table 2 gives some examples of specific strategies required for climate change mitigation and adaptation along with health co-benefits in the context of improved construction.

\section{Improved governance as a component of systems approaches}

Traditional approaches to dealing with urban development and health are largely dissociated one from the other. For example, decisions about short- or long-term investments in development of water and sewage infrastructure rarely involve consultation with health specialists, departments or ministries. The same is true for transportation and land-use. Conversely, health departments rarely involve stakeholders in urban development in investment decisions for health infrastructure or services.

Strengthening governance through the application of systems approaches could help realize the health co-benefits of a low carbon urban development path and lead to improved management of both climate change and health. This alignment of different development needs would improve the effectiveness and efficiency of urban interventions in both sectors 35 .

Table 2

Strategies for climate change mitigation and adaptation with health co-benefits in buildings.

\begin{tabular}{|c|c|c|}
\hline Adaptation/Mitigation tactic & Environmental outcomes & Health co-benefits \\
\hline Green roofs & $\begin{array}{c}\text { Carbon sequestration, water retention, energy } \\
\text { conservation, reduced greenhouse gas emissions, UHI } \\
\text { mitigation }\end{array}$ & $\begin{array}{c}\text { Reduce temperature-related illnesses and respiratory } \\
\text { illnesses, increase thermal comfort, increase contact with } \\
\text { nature, increase food security }\end{array}$ \\
\hline Increase albedo & $\begin{array}{c}\text { Reduce energy use and greenhouse gas emissions, UHI } \\
\text { mitigation }\end{array}$ & $\begin{array}{l}\text { Reduce temperature-related illnesses and respiratory } \\
\text { illnesses, increase thermal comfort }\end{array}$ \\
\hline LEED building compliance & $\begin{array}{l}\text { Increase energy efficiency of buildings, reduce energy } \\
\text { use and greenhouse gas emissions }\end{array}$ & $\begin{array}{l}\text { Reduce temperature-related illnesses and respiratory } \\
\text { illnesses, positive aspects of increased natural light in } \\
\text { workplace }\end{array}$ \\
\hline Home insulation & $\begin{array}{c}\text { Increase energy efficiency of buildings, reduce energy } \\
\text { use and greenhouse gas emissions }\end{array}$ & $\begin{array}{l}\text { Increase thermal comfort, reduce heat-related illnesses } \\
\text { and respiratory illnesses }\end{array}$ \\
\hline Solar panel and water heater & $\begin{array}{l}\text { Reduce energy use and greenhouse gas emissions, } \\
\text { reduce fossil fuel extraction }\end{array}$ & Reduce heat-related illnesses and respiratory illnesses \\
\hline
\end{tabular}

LEED: leadership in energy \& environmental design; UHI: urban heat island. 


\section{Governance in urban areas}

Governance refers to the institutions and processes through which societies manage the course of affairs at various scales. It can be polycentric and comprises institutions and processes enshrined in formal rules (e.g., constitutions and laws), private actors (civil society, non-governmental organizations - NGOs, communities, and businesses) and also informal activities and processes 53 . Aside from efficiency in delivering specific policy results, "good governance", as a policy objective, denotes the ethical procedural functioning of a governance system, encompassing such values as participation, transparency, accountability, decency, sustainability or fairness 53 .Thus, it inherently incorporates the systems principles of inter- and transdisciplinarity. Beyond measures of process, effective governance yields positive outcomes - indeed, good governance provides a favorable context for sustainable development 54 , and may particularly influence the social determinants of health 53 . For example, increasing citizen participation in urban investments through participatory budgeting has had positive impacts on public health, including reduction in health inequalities 26. Many of the investments chosen by communities in their areas addressed the underlying causes of urban health problems, such as lack of sanitation.

Urban areas are complex systems, dynamic in time and diverse in space. Their governance frameworks vary widely and depend on national and local conditions. Moreover, there are great disparities in resources and capacity between cities in higher versus middle- and low-income settings. Yet some commonalities also exist 55, notably the profusion of public and private urban actors, working at different levels of governments (national, regional, local, or even international) and at various physical scales, sometimes beyond the legal boundaries of a city. Indeed, issues of scaling/bounding are one common feature of systems problems. Another common feature of urban governance frameworks is an evolutionary trend from a government approach in which legitimacy relies largely on authority towards a governance approach involving more stakeholders in decision-making processes 56 . Where this is the case, values and tools such as participation, accountability, and legitimacy have assumed greater weight in political discourses. Finally, cities are highly contested places, where land tenure, shelter and economic development are critical issues and all have important impacts on the health and wellbeing of citizens 55 .

Against this backdrop, three areas 57 under the broad framework of governance offer prom- ise for innovative thinking and more effective outcomes: understanding the urban context; engaging and organizing stakeholders; and ensuring effectiveness. Although the original authors separated "engaging" and "organizing". We have addressed them jointly, as they often overlap - a point acknowledged in their original work 57 . We now analyze those areas and provide examples from different contexts.

\section{Understanding the context}

Improving governance through systems approaches requires a sufficiently complete overview of the context within which health - or lack thereof - arises. In fact, although climate change is a global phenomenon, its impacts depend to a large extent on local conditions 58 . It is thus critical to understand local vulnerability - "the degree to which a system is susceptible to, and unable to cope with, adverse effects of climate change" 59 (p. 89). Vulnerability itself is determined by a system's exposure, sensitivity ("the degree to which a system is affected, either adversely or beneficially, by climate variability or climate change") 59 (p. 86) and adaptive capacity ("the whole of capabilities, resources and institutions of a country or region to implement effective adaptation measures") 59 (p. 76).

Systems thinking offers a way to identify opportunities for action, and in some cases to identify potential co-benefits of sectoral policies. Perspectives from both natural and social sciences are helpful in highlighting sources of vulnerability. Thorough analysis also requires mapping of urban actors and their powers and interactions, as well as influential policies and institutions. To fully comprehend vulnerability in urban settings, the knowledge of local dwellers is also key, as they experience and notice changes on the ground. Collaboration between scientists, other urban actors, and local populations - i.e. inter- and transdisciplinarity - is therefore a first step in the process of adapting and reforming systems that assure urban health and wellbeing (Figure 1).

\section{Identifying, engaging and organizing stakeholders}

Systems approaches to urban health issues call for participatory and inclusive decision-making processes 27 , which can identify co-benefits that might otherwise be overlooked in a more sectoral, top-down approach. This requires involving all stakeholders in a given city, including communities and citizens, public authorities, businesses and even external actors, such as funding agencies. Two steps can set the stage for 


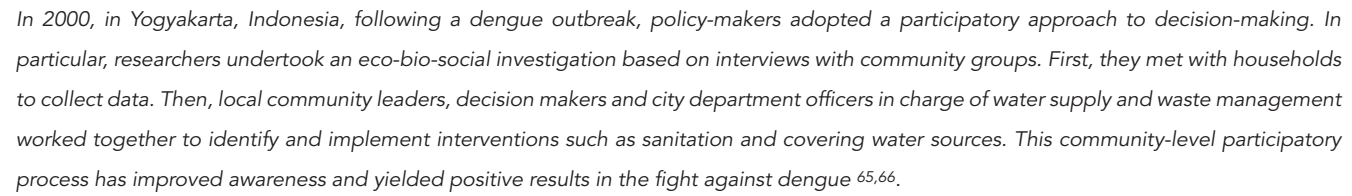

effective participatory processes: first, empower citizens through awareness-raising activities and establish common interests groups to prepare participation; second, facilitate dialogue and collaboration between urban actors.

Empowering people is especially important for the poorest segment of the population which is also often the most vulnerable to the impacts of climate change on health. For instance, lack of tenure rights and access to essential services experienced by slum dwellers affects their livelihoods and health. Gathering people in groups of shared interests raises their profile. People are thus easier to reach and capacity-building schemes can be tailored to their needs. It is then important to design policy processes in such a way as to ensure that these different groups meet and are heard. This can ease the acceptance of norms later on and thus increase their legitimacy 60 . At the same time, a multi-stakeholder approach is also relevant within governments to overcome sectoral barriers. In fact, some sectoral activities may generate co-benefits across sectors (Figure 2).

\section{Ensuring the effectiveness of decisions, norms and governance frameworks}

From a systems perspective, one aspect of better governance is the implementation of the policies and enforcement of the agreements and norms adopted through participatory and other decision-making processes. Decision-makers should be held accountable and citizens informed of activities undertaken to that end. In addition, mechanisms to enforce those "negotiated" laws and regulations, for instance judicial proceedings, are a key complementary tool to make sure that policy-makers and individuals' duties and rights are upheld.

In this regard, the rights-based approach is a conceptual framework used by development agencies to promote the empowerment of peo- ple through their capacity to know and claim the protection of human rights. In the urban context, citizens demand the provision of basic services such as waste management, clean water availability and education. These then become standards that public authorities have to meet. Against this background, judges may have to protect citizens from interventions by the public and private sectors, such as land evictions, when they have an impact on health and wellbeing 61 (Figure 3).

\section{Discussion and conclusions}

Systems approaches are an essential element of improved governance geared toward dealing more effectively with the complex interactions between environmental change and urban health. Good governance could facilitate a cobenefits perspective and strengthen decisionmaking and implementation of urban development interventions. Although progress towards these goals will be gradual, we propose five steps to facilitate this transition.

First, there is a need for improving understanding and coordination among different sectors. Cities are highly complex environments, yet they are still largely managed in the form of discrete departments. Pincetl 62 traces the codevelopment of disciplines, institutions and administrative structures (notably the planning profession, civil engineering, and the National Water Quality Association) during urban expansion in the United States around the turn of the 20th century to mitigate the worst aspects of urbanization and create what Melosi 63 termed the sanitary city. Whilst this seemed an appropriate way to plan for growing cities, it is becoming clear that the interactions of many of these elements cannot be effectively managed. The city divisions of health, transport, planning and environment are derived from a variety of different intellectual 
Figure 2

Networking community groups for health in Rio de Janeiro, Brazil.

In 2004, in Rio de Janeiro, Brazil, a network of community groups (the Network of Healthy Communities) representing over 1.3 million people was founded. The groups are various and represent different interests such as religious, cultural or human rights groups. The network works directly with the local Centre for Health Promotion. This representation of the interests of diverse groups of city inhabitants to a public authority has allowed the direct presentation and prioritization of local needs. The various stakeholders slowly formed a partnership and undertook development programs, tackling health-related issues such as prevention of diseases and poor nutrition 55. The Network is a good example of a social initiative where poor populations organize themselves in a collective and participatory way to influence public policy and strive for better conditions of life in disadvantaged settings, like the favelas 67.

Figure 3

The role of the judicial system in urban health governance: the case of New Delhi, India.

In India, the Supreme Court has associated the right to life, enshrined in the Constitution, with the right to live in a healthy environment.

Public interest litigation (PIL) allows those whose fundamental rights have been violated to bypass ordinary legal proceedings and address the

Supreme Court directly 68,69. Environmental groups and activist lawyers soon understood the opportunities inherent in this legal mechanism.

On this basis, several PILs were filed in the 1980s to draw attention to the high level of air pollution in Delhi and its impacts on health. The

Center for Science and Environment (CSE) published a book 70 highlighting an estimated 10,000 people per year (more than one an hour) were

dying prematurely due to air pollution in Delhi 71 - and a recent analysis suggests this figure continues to rise 72 . As vehicular pollution accounts

for $64 \%$ of the total pollution load in Delhi 68,73, the Court made decisions ordering the governments of the National Capital Territory of Delhi

and the Union of India to enforce existing environmental legislation. It also supported the establishment of a permanent Environment Pollution

(Prevention and Control) Authority for the National Capital Region. The Court also issued more technical orders, such as the conversion of

the entire bus fleet to compressed natural gas - a clean fuel - within three years 68 . Studies showed that the norms adopted as a consequence

of the court's activity have had a beneficial effect on air quality in Delhi for some time. In particular the level of suspended particulate matters

has decreased by $26 \% 68,74$.

traditions, which, while (usually) competent for their given remit, generally address any emergent urban problem using the tools most comfortable to their practitioners. This runs the risk of creating gaps in coverage of important issues, or worse, generating internecine conflict when attempting to implement cross-cutting strategies aimed to address an emergent problem. Paralysis may ensue, with poor coordination or even competition between these fragmented governance frameworks. We must therefore create the institutional mechanisms and incentives to enable these sectors to effectively work together.

Second, we need to think about the design of service providers and reforms carried forward, particularly in recent decades, which have aggravated the problems described in the previous paragraph. Trends in public management, such as corporatization and privatization of certain public services, can exacerbate cross-sectoral problems, as results-based organizations are reluctant or unwilling to share resources or information with other organizations, implying, as this does, higher costs or loss of competitive advantage 64 . Designing services in such a way that providers can be held accountable to the public and are prepared to work together would allow for a more systematic approach to issues of climate change and urban health.

Third, we should make greater efforts to bring together different civil society stakeholders in the decision-making process. Civil society is capable of merging various knowledge systems and perspectives over the same issue. For example, participatory initiatives could identify the main concerns and likely reactions of local popula- 
tions towards potential urban interventions, as happened in the case of participatory budgeting in Belo Horizonte, Brazil 26. Broad and open consultations about short- and long-term development plans could help to incorporate other views and information in development pathways, leading to improved decision-making and possibly to increases in co-benefits.

Fourth, systems approaches are not silver bullets capable of resolving all problems with a single policy. Transport, energy and land-use planning often complement each other but their health effects can be quite different. For example, green areas, which are considered good for city ambience, exercise and mental health, must not come at the expense of an expansive urban form with increased reliance on high levels of personal transit, nor should they provide conditions for the spread of vector-borne diseases. The inherent complexity of these issues underscores the fact that no single policy is a panacea. However, there are generally too many plans, with not enough thought given to coordination and implementation. We highlight the need for systems approaches as a means to better integrate sectors and that seeking out co-benefits can facilitate such integration.

Fifth, in moving towards systems approaches in urban health, tools that explicitly and quantitatively estimate health co-benefits can improve sectoral integration and decision-making 36 . However, to move beyond the modelling stage, consideration needs to be given to how such measures can be implemented at the city scale. Critically, we must move beyond the siloed thinking that exists across sectors and urban governance. Training policy-makers in simple systems thinking and systems interactions will be beneficial, however ultimately there needs to be a change in the incentive structure in governance that rewards addressing urban issues from a systemic rather than a sectoral standpoint.

\section{Resumen}

“Co-beneficios" es un término que se refiere a los impactos positivos de una política que van más allá de los resultados esperados, con frecuencia en sectores distintos. En el contexto urbano, las políticas en determinados sectores (como el transporte, la energía o la gestión de residuos) muchas veces generan co-beneficios múltiples en otros sectores. Entre dichos beneficios se incluye la reducción de los impactos ambientales a nivel local o mundial e incluso en el ámbito de la salud pública. Entre las acciones claves para la identificación y realización de co-beneficios se incluye la adopción de un enfoque sistémico-analítico para entender los vínculos intersectoriales y, en particular, la traducción de este entendimiento en mejor gobernanza a nivel de sectores específicos y municipalidades. Este artículo repasa una serie de políticas que puedan generar co-beneficios para la salud y el clima a través de distintos sectores urbanos. Por medio de casos ejemplares, ilustra cómo un abordaje por sistemas puede producir innovaciones en la gobernanza urbana que faciliten el desarrollo de ciudades sanas y sostenibles.

Políticas Públicas; Evaluación del Impacto en la Salud; Salud Urbana

\section{Contributors}

All authors contributed to the drafting and revision of the paper.

\section{Acknowledgments}

Magali Dreyfus is grateful to the AXA Research Fund for its support (Postdoctoral Fellowship). Hooman Farzaneh thanks the Japan Society for the Promotion of Science through the JSPS-UNU Postdoctoral Fellowship for its support. 


\section{References}

1. Rockström J, Steffen W, Noone K, Persson A, Chapin FS, Lambin EF, et al. A safe operating space for humanity. Nature 2009; 461:472-5.

2. Steffen W, Persson A, Deutsch L, Zalasiewicz J, Williams M, Richardson $\mathrm{K}$, et al. The anthropocene: from global change to planetary stewardship. Ambio 2011; 40:739-61.

3. Hoornweg D, Sugar L, Gómez CLT. Cities and greenhouse gas emissions: moving forward. Environ Urban 2011; 23:207-27.

4. Capon AG, Synnott ES, Holliday S. Urbanism, climate change and health: systems approaches to governance. N S W Public Health Bull 2009; 20:24-8.

5. Costello A, Abbas M, Allen A, Ball S, Bell S, Bellamy R, et al. Managing the health effects of climate change. Lancet and University College London Institute for Global Health Commission. Lancet 2009; 373:1693-733.

6. McMichael T, Montgomery H, Costello A. Health risks, present and future, from global climate change. BMJ 2012; 344:e1359.

7. Solomon S, Qin D, Manning M, Chen Z, Marquis M, Averyt KB, et al., editors. Climate change 2007: the physical science basis. Contribution of Working Group I to the Fourth Assessment Report of the Intergovernmental Panel on Climate Change. Cambridge/New York: Cambridge University Press; 2007.

8. Godber OF, Wall R. Livestock and food security: vulnerability to population growth and climate change. Glob Change Biol 2014; 20:3092-102.

9. McMichael C, Barnett J, McMichael AJ. An ill wind? Climate change, migration, and health. Environ Health Perspect 2012; 120:646-54.

10. Butler CD, Harley D. Primary, secondary and tertiary effects of eco-climatic change: the medical response. Postgrad Med J 2010; 86:230-4.

11. McMichael AJ. Climate change and global health. In: Butler CD, editor. Climate change and global health. Oxfordshire: CABI; 2014. p. 11-20.

12. Butler $\mathrm{CD}$, editor. Climate change and global health. Oxfordshire: CABI; 2014.

13. Bambrick HJ, Capon AG, Barnett GB, Beaty RM, Burton AJ. Climate change and health in the urban environment: adaptation opportunities in Australian cities. Asia Pac J Public Health 2011; 23(2 Suppl):67S-79.

14. McGranahan G, Balk D, Anderson B. The rising tide: assessing the risks of climate change and human settlements in low elevation coastal zones. Environ Urban 2007; 19:17-37.

15. Nicholls RJ, Marinova N, Lowe JA, Brown S, Vellinga P, de Gusmão D, et al. Sea-level rise and its possible impacts given a "beyond $4^{\circ} \mathrm{C}$ world" in the twenty-first century. Philos Trans A Math Phys Eng Sci 2011; 369:161-81.

16. Obokata R, Veronis L, McLeman R. Empirical research on international environmental migration: a systematic review. Popul Environ 2014; 36:111-35.

17. Stone B, Hess JJ, Frumkin H. Urban form and extreme heat events: are sprawling cities more vulnerable to climate change than compact cities? Environ Health Perspect 2010; 118:1425-8.
18. Klinkenberg E, McCall P, Wilson MD, Amerasinghe FP, Donnelly MJ. Impact of urban agriculture on malaria vectors in Accra, Ghana. Malar J 2008; 7:151.

19. Stoler J, Weeks JR, Getis A, Hill AG. Distance threshold for the effect of urban agriculture on elevated self-reported malaria prevalence in Accra, Ghana. Am J Trop Med Hyg 2009; 80:547-54.

20. Dongus S, Nyika D, Kannady K, Mtasiwa D, Mshinda H, Gosoniu L, et al. Urban agriculture and Anopheles habitats in Dar es Salaam, Tanzania. Geospat Health 2009; 3:189-210.

21. Brisbois BW, Ali SH. Climate change, vector-borne disease and interdisciplinary research: social science perspectives on an environment and health controversy. EcoHealth 2010; 7:425-38.

22. D'Amato G, Baena-Cagnani CE, Cecchi L, AnnesiMaesano I, Nunes C, Ansotegui I, et al. Climate change, air pollution and extreme events leading to increasing prevalence of allergic respiratory diseases. Multidiscip Respir Med 2013; 8:12.

23. De Sario M, Katsouyanni K, Michelozzi P. Climate change, extreme weather events, air pollution and respiratory health in Europe. Eur Respir J 2013; 42:826-43.

24. Proust K, Newell B, Brown H, Capon A, Browne C, Burton A, et al. Human health and climate change: leverage points for adaptation in urban environments. Int J Environ Res Public Health 2012; 9:2134-58.

25. Tran KV, Azhar GS, Nair R, Knowlton K, Jaiswal A, Sheffield P, et al. A cross-sectional, randomized cluster sample survey of household vulnerability to extreme heat among slum dwellers in Ahmedabad, india. Int J Environ Res Public Health 2013; 10:2515-43.

26. Caiaffa WT, Nabuco AL, Friche AA, Proietti FA. Urban health and governance model in Belo Horizonte, Brazil. In: Vlahov D, Boufforf JI, Pearson C, Norris L, editors. Urban health: global perspectives. New York: John Wiley \& Sons; 2010. p. 437-52.

27. International Council for Science. Report of the ICSU Planning Group on Health and Wellbeing in the Changing Urban Environment: a systems analysis approach. Paris: International Council for Science; 2011.

28. Bai X, Nath I, Capon A, Hasan N, Jaron D. Health and wellbeing in the changing urban environment: complex challenges, scientific responses, and the way forward. Curr Opin Environ Sustain 2012; 4:465-72.

29. Haines A, Alleyne G, Kickbusch I, Dora C. From the Earth Summit to Rio+20: integration of health and sustainable development. Lancet 2012; 379:2189-97.

30. Hovmand PS. Analyzing dynamic systems: a comparison of structural equation modeling and system dynamics modeling. In: Pugesek BH, Tomer A, von Eye A, editors. Structural equation modeling: applications in ecological and evolutionary biology. Cambridge: Cambridge University Press; 2003. p. 212-34. 
31. Lawrence RJ. Deciphering interdisciplinary and transdisciplinary contributions. Transdisciplinary Journal of Engineering \& Science 2010; 1:111-6.

32. Newell B, Proust K. Introduction to collaborative conceptual modelling. Canberra: Australian National University; 2012.

33. Doll CNH, Dirgahayani P, Gasparatos A. Urban mobility co-benefits and their contribution to sustainable urban development: a developing country perspective. Proceedings of the Asian Planning Schools Association Congress 2011; T-1-8:1308-17.

34. Menikpura SNM, Sang-Arun J, Bengtsson M. Integrated solid waste management: an approach for enhancing climate co-benefits through resource recovery. J Clean Prod 2013; 58:34-42.

35. Puppim de Oliveira JA, Doll CNH, Kurniawan TA, Geng Y, Kapshe M, Huisingh D. Promoting winwin situations in climate change mitigation, local environmental quality and development in Asian cities through co-benefits. J Clean Prod 2013; 58:1-6.

36. Doll CNH, Balaban O. A methodology for evaluating environmental co-benefits in the transport sector: application to the Delhi metro. J Clean Prod 2013; 58:61-73.

37. Paton K, Sengupta S, Hassan L. Settings, systems and organization development: the Healthy Living and Working Model. Health Promot Int 2005 ;20:81-9.

38. Woodcock J, Edwards P, Tonne C, Armstrong BG, Ashiru O, Banister D, et al. Public health benefits of strategies to reduce greenhouse-gas emissions: urban land transport. Lancet 2009; 374:1930-43.

39. Frumkin H. Urban sprawl and public health. Public Health Rep 2002; 117:201-17.

40. Pendola R, Gen S. BMI, auto use, and the urban environment in San Francisco. Health Place 2007; 13:551-6.

41. Day K, Alfonzo M, Chen Y, Guo Z, Lee KK. Overweight, obesity, and inactivity and urban design in rapidly growing Chinese cities. Health Place 2013; 21:29-38.

42. Swinburn B, Egger G, Raza F. Dissecting obesogenic environments: the development and application of a framework for identifying and prioritizing environmental interventions for obesity. Prev Med 1999; 29(6 Pt 1):563-70.

43. Townshend T, Lake AA. Obesogenic urban form: theory, policy and practice. Health Place 2009; 15:909-16.

44. Doll CNH. Spatial analysis of the World Bank's global urban air pollution dataset. Laxenburg: International Institute for Applied Systems Analysis; 2009. (Report, IR-09-033).

45. World Health Organization. 7 million premature deaths annually linked to air pollution. http:// www.who.int/mediacentre/news/releases/2014/ air-pollution/en/ (accessed on 02/Dec/2014).

46. European Commission. The multifunctionality of green infrastructure. Brussels: European Commission; 2012

47. Tzoulas K, Korpela K, Venn S, Yli-Pelkonen V, Ka mierczak A, Niemela J, et al. Promoting ecosystem and human health in urban areas using Green Infrastructure: a literature review. Landsc Urban Plan 2007; 81:167-78.
48. Bowler DE, Buyung-Ali LM, Knight TM, Pullin AS. A systematic review of evidence for the added benefits to health of exposure to natural environments. BMC Public Health 2010; 10:456.

49. Mulligan K, Elliott SJ, Schuster-Wallace C. The place of health and the health of place: dengue fever and urban governance in Putrajaya, Malaysia. Health Place 2012; 18:613-20.

50. World Health Organization. Fuel for life: household energy and health. Geneva: World Health Organization; 2006.

51. Smith K. Risk transition and global warming. Journal of Energy Engineering 1990; 116:178-88.

52. Liddell C, Morris C. Fuel poverty and human health: a review of recent evidence. Energy Policy 2010; 38:2987-97.

53. Burris S, Hancock T, Lin V, Herzog A. Emerging strategies for healthy urban governance. J Urban Health 2007; 84 Suppl 1:154-63.

54. Kemp R, Parto S. Governance for sustainable development: moving from theory to practice. International Journal of Sustainable Development 2005; 8:12-30.

55. Barten F, Akerman M, Becker D, Friel S, Hancock T, Mwatsama M, et al. Rights, knowledge, and governance for improved health equity in urban settings. J Urban Health 2011; 88:896-905.

56 . Rhodes RAW. The new governance: governing without government. Polit Stud (Oxf) 1996; 44:652-67.

57. Mayers J, Morrison E, Rolington L, Studd K, Turrall S. Improving governance of forest tenure: a practical guide. London: International Institute for Environment and Development/Rome: Food and Agriculture Organization of the United Nations; 2013.

58. Moensch M, Tyler S, Lage J. Catalyzing urban climate resilience: applying resilience concepts to planning practice in the ACCCRN Program. Boulder: ISET-International; 2011.

59. Intergovernmental Panel on Climate Change. Glossary Fourth Assessment Report. Geneva: Intergovernmental Panel on Climate Change; 2007.

60. Bernstein S. Legitimacy in global environmental governance. Journal of International Law and International Relations 2004; 1:139-66.

61. Emmel ND, D'Souza L. Health effects of forced evictions in the slums of Mumbai. Lancet 1999; 354:1118.

62. Pincetl S. From the sanitary city to the sustainable city: challenges to institutionalising biogenic (nature's services) infrastructure. Local Environ 2010; 15:43-58.

63. Melosi M. The Sanitary City: urban infrastructure in America from colonial times to the present. Baltimore: The Johns Hopkins University Press; 1999.

64. McDonald D, editor. Rethinking corporatization and public services in the global south. http:/ /www. palgrave.com\%2Fpage\%2Fdetail\%2Frethinkingcorporatization-and-public-services-in-theglobal-south-david-mcdonald\%2F\%3FK\%3D97 81783600182 (accessed on 02/Oct/2014).

65. Katz R, Mookherji S, Kaminski M, Haté V, Fischer JE. Urban governance of disease. Adm Sci 2012; 2:135-47. 
66. Tana S, Umniyati S, Petzold M, Kroeger A, Sommerfeld J. Building and analyzing an innovative community-centered dengue-ecosystem management intervention in Yogyakarta, Indonesia. Pathog Glob Health 2012; 106:469-78.

67. Becker D, Edmundo KB, Guimarães W, Vasconcelos MS, Bonatto D, Nunes NR, et al. Network of healthy communities of Rio de Janeiro, Brazil. Promot Educ 2007; 14:101-2.

68. Rajamani L. Public interest environmental litigation in India: exploring issues of access, participation, equity, effectiveness and sustainability. J Environ Law 2007; 19:293-321.

69. Dreyfus M. The Judiciary's role in environmental governance, the case of Delhi. Environmental Policy and Law 2013; 43:162-74.

70. Sharma A, Roychowdhury A. Slow murder: the deadly story of vehicular pollution in India. New Delhi: Centre for Science and Environment; 1996.
71. Faiz A, Sturm PJ. New directions: air pollution and road traffic in developing countries. Atmos Environ 2000; 34:4745-6.

72. Nagpure AS, Gurjar BR, Martel JC. Human health risks in national capital territory of Delhi due to air pollution. Atmos Pollut Res 2014; 5:371-80.

73. Central Pollution Control Board. Pollution statistics 1993-1994. New Delhi: Central Pollution Control Board; 1995.

74. Centre for Science and Environment. Leapfrog factor: clearing the air in Asian cities. New Delhi: Centre for Science and Environment; 2006.

Submitted on $27 / \mathrm{Jan} / 2015$

Final version resubmitted on $02 / \mathrm{Jul} / 2015$

Approved on 06/Jul/2015 